\title{
ANALISIS FUNDAMENTAL MAKRO DAN INTEGRASI PASAR SAHAM DUNIA DENGAN BURSA EFEK INDONESIA
}

\author{
Luh Gede Sri Artini(1) \\ Nyoman Tri Aryati( ${ }^{(2)}$ \\ Putu Vivi Lestari ${ }^{(3)}$ \\ Ni Putu Ayu Darmayanti ${ }^{(4)}$ \\ Gede Merta Sudiartha ${ }^{(5)}$ \\ (1),(2),(3),(4),(5)Fakultas Ekonomi dan Bisnis Universitas Udayana, Bali, Indonesia \\ email :lg_artini@yahoo.com
}

\begin{abstract}
ABSTRAK
Penelitian ini merupakan gabungan dari penelitian sebelumnya mengenai hubungan antara harga saham dengan kinerja ekonomi makro, dan penelitian mengenai integrasi Pasar Modal internasional.Variabel ekonomi makro dalam penelitian ini dibatasi pada pertumbuhan PDB, tingkat suku bunga SBI dan nilai Kurs dolar Amerika terhadap Rupiah dan Indeks saham digunakan adalah Indeks Dow Jones, Indeks Saham Australia, Indeks Shanghai dan Indeks Singapura. Data dikumpulkan dari tahun 2011 sampai tahun 2015 secara bulanan dengan teknik analisis regresi linier dengan bantuan Statistical Package For Social Science (SPSS). Hasil penelitian menunjukkan bahwa secara simultan PDB, SBI dan Kurs serta Indeks Dow Jones, Indeks Australia, Indeks Shanghai dan Indeks Singapura berpengaruh signifikan terhadap IHSG. Secara parsial PDB, DJI dan STI berpengaruh positif dan signifikan terhadap IHSG, SBI berpengaruh negatif signifikan terhadap IHSG, Kurs, ASX200 dan SSE berpengaruh negatif tidak signifikan terhacap IHSG
\end{abstract}

Kata kunci : indeks pasar saham, variabel makro

\begin{abstract}
The objective of this paper are to analyze the movement of macroeconomic variables in Indonesia and examine the degree of five stock market integration in Indonesia, USA, Australia, China and Singapore based on data from 2010 to 2014 with the period of observation January 2011 -December 2015. Regression model is used to analysis the effect of economic factor (GDP, interest rate and exchange rate) and Dow Jones Composite Index, Australian Index, Shanghai stock index and Singapore. to the movement of the Indonesian composite stock market index in Indonesian Capital Market. The results of this research indicate GDP, DJI, and STI have significant positive effect on IHSG, interest rate have significant negative effect on IHSG. While exchange rate, ASX and SSE have insignificant negative effect
\end{abstract}

Keywords: macro economic variables, stock market index

\section{PENDAHULUAN}

Globalisasi perekonomian dunia mengakibatkan ketergantungan ekonomi antar negara yang sangat tinggi. Investasi keuangan berpengaruh besar terhadap pergerakan modal asing yang masuk ke pasar keuangan di suatu negara. Salah satu pasar keuangan yang memiliki fungsi perantara adalah pasar modal, pasar modal merupakan pasar instrumen keuangan jangka panjang yang memperjualbelikan hutang maupun modal sendiri yang diterbitkan pemerintah maupun perusahaan swasta (Husnan, 2015:3).

Pasar modal berperan penting bagi perekonomian suatu Negara berdasarkan dua fungsi pasar modal, yaitu fungsi ekonomi dan fungsi keuangan. Fungsi ekonomi sebagai sarana bagi perusahaan untuk mendapatkan dana dari masyarakat pemodal (investor). Fungsi keuangan pasar modal menawarkan kesempatan memperoleh imbalan (return) bagi pemilik modal (Anoraga, 2010):

Analisis fundamental mengindentifikasi dan mengukur faktor-faktor yang menentukan nilai intrinsik instrumen finansial. Husnan (2015:307), menyatakan "Analisis fundamental memperkirakan harga saham dimasa yang akan datang dengan mengestimasi faktor-faktor fundamental yang mempengaruhi harga saham dimasa yang akan datang dan menerapkan hubungan variabel-variabel tersebut sehingga diperoleh taksiran harga saham. Tandelillin (2010) menyatakan investor bisa melakukan analisis fundamental secara "top-down" yang meliputi, analisis variabel-variabel ekonomi makro yang mempengaruhi kinerja seluruh perusahaan, analisis industri-industri pilihan yang 
berprospek paling baik dan analisis perusahaan dan penentuan saham perusahaan yang terbaik.

Beberapa variabel ekonomi makro yang perlu diperhatikan investor antara lain: PDB, Inflasi, Tingkat bunga, Kurs rupiah, Anggaran defisit, Investasi swasta, Neraca perdagangan dan pembayaran. Faktor-faktor makro ekonomi yang secara langsung dapat mempengaruhi kinerja saham maupun kinerja perusahaan antara lain tingkat suku bunga domestik, kurs valuta asing, kondisi perekonomian internasional, siklus ekonomi suatu negara, tingkat inflasi, peraturan perpajakan, serta jumlah uang yang beredar (Samsul, 2008). Ketika kondisi makro ekonomi di suatu negara mengalami perubahan baik yang positif ataupun negatif, investor akan mengkalkulasikan dampaknya terhadap kinerja perusahaan di masa depan.

Berdasarkan Arbitrage Pricing Model (APT) indikator yang dijadikan pertimbangan investor dalam berinvestasi di pasar modal selain hal-hal yang bersifat fundamental yaitu variabel ekonomi makro : laju inflasi, suku bunga, serta nilai tukar mata uang asing, dan faktor teknikal atau eksternal juga memiliki potensi besar terhadap perubahan harga saham di pasar modal.

Pasar modal Indonesia (Bursa Efek Indonesia) telah menjadi bagian dari kegiatan bursa saham global (Shevanda, 2013). Liberalisasi pasar modal memungkinkan investor asing berinvestasi di pasar domestik dan investor domestik bertransaksi di negara lain. Investor bisa mendapatkan keuntungan lebih melalui diversifikasi portofolio saham dari berbagai indeks (Nikunj et al., 2012). Diversifikasi internasional memunculkan teori portofolio modern mengenai integrasi pasar modal internasional. Indeks pasar saham yang sangat terintegrasi menyiratkan manfaat diversifikasi internasional yang rendah, sedangkan pasar saham tersegmentasi memungkinkan manajer portofolio melakukan diversifikasi dan mendapatkan keuntungan dari perbedaan di pasar modal (Aviral et al., 2013).

Negara berkembang mengijinkan pemodal asing memiliki sekuritas yang diperdagangkan dengan maksud memancing capital inflows. Dengan jalan dual listing terhadap beberapa saham yang diterbitkan oleh perusahaan di dunia. Dual listing berarti saham tersebut terdaftar di bursa negara tempat perusahaan berdomisili dan juga di bursa luar negeri. Negara maju melakukan cross listing yang artinya beberapa saham di Indonesia terdaftar di bursa luar negeri dan sebaliknya beberapa saham luar negeri terdaftar di Pasar Modal Indonesia. Terbukanya kesempatan pembelian saham domestik oleh pemodal asing, terbuka dan membeli saham asing bagi pemodal domestic berarti terjadi capital inflows dan capital outflows (Husnan, 2015:225).

Terdapat pengertian integrasi pasar modal dunia. Pengerttian yang pertama menurut teori Capital Asset Pricing Model, yaitu bahwa pasar modal dipertimbangkan sudah terintegrasi apabila surat berharga dengan karakteristik risiko yang sama memiliki harga yang sama, walaupun diperdagangkan di pasar modal yang berbeda (Bodie, Kane \&Markus, 2014).

Terjadinya fenomena menyangkut hubungan. antara variabel makro ekonomi dengan pergerakan IHSG tidak konsisten dengan teori yang ada, tentu hal ini merupakan fenomena yang menarik untuk diteliti mengapa terjadi penyimpangan seperti itu. Selain itu hasil penelitian terdahulu mengenai pengaruh PDB, Suku bunga, kurs rupiah terhadap dolar Amerika Serikat, cenderung tidak konsisten atau berbeda antar penelitian satu dengan penelitian lainnya serta adanya integrasi pasar modal pada saat krisis keuangan dunia menunjukkan bahwa kondisi perekonomian negara maju akan berpengaruh terhadap perekonomian negara berkembang. Indonesia sebagai negara berkembang yang memiliki pasar modal yang sedang berkembang, namun masih tergolong rentan terhadap kondisi makro ekonomi dunia secara umum. Negara yang memiliki ekonomi yang lebih kuat mempunyai kecenderungan untuk mendominasi negara yang memiliki perekonomian lebih lemah (Ludovicus, 2006). Sebagaimana telah dijelaskan bahwa indeks harga saham adalah cerminan dari perekonomian suatu negara, sehingga indeks harga saham suatu negara yang kuat akan berpengaruh terhadap indeks harga saham dari negara yang lemah.

Penelitian mengenai pengaruh variabel Makro terhadap Indeks Harga Saham dan integrasi pasar modal telah banyak dilakukan oleh para peneliti. Di Indonesia, penelitian tentang pengaruh Indeks Bursa Asing dan factor fundamental makro terhadap Indeks Harga Saham Gabungan (IHSG) dilakukan oleh Pramushinta (2012) dengan judul Analisis Pengaruh Pergerakan Indeks Bursa Asing, Tingkat Inflasi, Harga Minyak Mentah Dunia, Nilai Tukar Rupiah Atas Dollar Amerika Terhadap Indeks Harga Saham Gabungan (IHSG) Di Bursa Efek Indonesia (BEI). Hasil analisis yang diperoleh bahwa Indeks Dow Jones berpengaruh negatif signifikan terhadap IHSG, untuk Indeks New York Stock Exchange berpengaruh positif tidak signifikan terhadap IHSG, Indeks Nikkei berpengaruh negatif sinifikan terhadap 
IHSG, Indeks Nasdaq berpengaruh positif signifikan terhadap IHSG, Indeks Footsie berpengaruh positif tidak signifikan terhadap IHSG, tingkat inflasi berpengaruh positif namun tidak signifikan, harga minyak dunia berpengaruh negatih namun tidak signifikan untuk nilai tukar rupiah terhadap dollar Amerika secara parsial berpengaruh negatif signifikan terhadap IHSG

Murtianingsih (2012) meneliti tentang Variabel Ekonomi Makro Dan Indeks Harga Saham Gabungan bertujuan meneliti hubungan variabel ekonomi makro : inflasi, suku bunga BI, dan nilai tukar mata uang terhadap pergerakan IHSG di Bursa Efek Indonesia. Hasil penelitian ini menemukan bahwa inflasi, suku Bunga BI, Nilai Tukar mata uang terhadap Dollar berpengaruh signifikan terhadap pergerakan IHSG. Sementara pengaruh secara parsial menghasilkan : inflasi berpengaruh positif terhadap IHSG meskipun tidak signifikan, sedangkan suku bunga BI dan nilai tukar mata uang rupiah terhadap Dollar berpengaruh negatif signifikan.

Berdasarkan analisis fundamental ekonomi makro dan diversifikasi internasional maka investor saham di pasar modal Indonesia agar dapat memperoleh return yang lebih tinggi dapat mempertimbangkan pertumbuhan PDB, tingkat suku bunga Sertifikat Bank Indonesia (SBI) dan nilai Kurs dolar Amerika terhadap Rupiah serta integrasi pasar modal Amerika, Australia, Shanghai dan Singapura terhadap Pasar Modal Indonesia.

\section{METODE PENELITIAN}

Penelitian ini termasuk ke dalam riset eksplanatori. Penelitian ini dilakukan dengan menggunakan paradigma asosiatif. Pada penelitian ini akan dilakukan analisis untuk mengetahui bagaimana pengaruh untuk mengetahui bagaimana pengaruh PDB, tingkat suku bunga Sertifikat Bank Indonesia (SBI), nilai Kurs dolar Amerika atas Rupiah, Indeks Dow Jones, ASX200, Indeks Pasar Modal Shanghai dan Indeks Saham Singapura terhadap Indeks Harga Saham (IHSG) BEI pada periode Januari 2011-Desember 2015.

Indeks Harga Saham Gabungan (Y). Variabel Dependen adalah Indeks Harga Saham Gabungan (IHSG) Indonesia yang merupakan perbandingan atau proporsi dari total harga semua saham pada tahun yang berlaku dengan total harga saham pada waktu dasar. IHSG adalah indeks yang terdapat di Bursa Efek Indonesia. Data IHSG yang digunakan dari periode Januari 2011-Desember 2015.

Produk Domestik Bruto (X1). Produk Domestik Bruto dalam penelitian ini adalah Produk Domestik
Bruto Atas Dasar Harga Konstan 2000 Menurut Lapangan Usaha (Miliar Rupiah) yang dipublikasikan oleh BPS dari periode Januari 2011Desember 2015.

Suku Bunga SBI. Suku Bunga SBI dalam penelitian ini menggunakan BI rate tanggal terakhir tiap bulan yang dipublikasikan oleh BI dari periode Januari 2011-Desember 2015 dalam satuan persentase.

Kurs Rupiah terhadap Dolar Amerika Serikat. Kurs Dolar Amerika Serikat Terhadap Rupiah dalam penelitian ini menggunakan Kurs tengah Dolar Amerika Serikat Terhadap Rupiah yang dipublikasikan oleh BPS dari periode Januari 2011Desember 2015 dalam satuan rupiah

Indeks Dow Jones (X1). Indeks Dow Jones (DJI) adalah indeks utama pada bursa saham New York Stock Exchange di Amerika dan perhitungannya menggunakan rata-rata 30 perusahaan.Jumlah tersebut mencerminkan hampir seperlima nilai pasar dari seluruh saham AS. Sebagai negara Adidaya, perekonomian Amerika memberikan pengaruh terbesar terhadap ekonomi di seluruh dunia, khususnya di Indonesia. Data DJI yang digunakan dari periode Januari 2011-Desember 2015.

Indeks ASX200. Indeks S\&P/ASX 200 adalah sebuah indeks pasar saham tertimbang kapitalisasi pasar di Saham Australia. Indeks saham ini terdiri dari 200 perusahaan Australia terbesar yang perdagangan pada Bursa Efek Australia dari Standard \& Poor's. Data indeks ASX 200 yang digunakan dari periode Januari 2011-Desember 2015.

SSE Composite Index. Indeks Komposit SSE adalah sebuah indeks pasar saham dari semua saham yang diperdagangkan di Bursa Saham Shanghai di Republik Rakyat Tiongkok. Indeks ini dikembangkan dengan nilai dasar 100 pada tanggal 19 Desember 1990. Indeks ini diluncurkan pada tanggal 15 Juli 1991. Data indeks SSE Composite Index yang digunakan dari periode Januari 2011Desember 2015.

Indeks Straits Times (X5). Indeks Straits Times (STI) adalah gabungan dari 30 perusahaan terbesar di pasar saham Singapura. Sebagai negara maju yang sangat berdekatan dengan Indonesia, perekonomian Singapura sangat berpengaruh terhadap Indonesia. Singapura dan Indonesia merupakan anggota ASEAN yang memiliki perjanjian ekonomi yaitu AFTA, dimana AFTA merupakan perjanjian ekonomi perdagangan bebas di kawasan Asia 
Tenggara. Data STI yang digunakan dari periode Januari 2011-Desember 2015.

Kelima indeks tersebut (IHSG, DJI, ASX200, SSE dan STI) dapat dihitung dengan menggunakan rumus indeks tak tertimbang sebagai berikut (Muzammil, 2011):

$$
\text { Indeks Harga Saham }=\frac{\Sigma \mathrm{Pt}}{\Sigma \mathrm{P}_{\mathrm{o}}} \times 100 \% \ldots \text { (1) }
$$

$\Sigma \mathrm{Pt}=$ Total Harga semua saham pada waktu yang berlaku

Po $=$ Total Harga Saham pada waktu dasar 2011 sampai dengan Desember 2015.

Metode pegumpulan data yang digunakan dalam penelitian ini dengan observasi nonpartisipan, data sekunder yang dikumpulkan selama 5 tahun dari tahun 2011 sampai tahun 2015 secara bulanan. Teknik analisis data dalam penelitian ini adalah analisis regresi linier berganda (multiple linear regresion analysis). Tujuan analisis ini adalah untuk mengetahui pengaruh pertumbuhan PDB, tingkat suku bunga Sertifikat Bank Indonesia (SBI) dan nilai Kurs dolar Amerika terhadap Rupiah dan Indeks Dow Jones, Indeks Pasar Modal Australia, Indeks Pasar Modal Shanghai dan Indeks Pasar Modal Singapura. Analisis Linier berganda ini menggunakan alat bantu Statistical Package For Social Science (SPSS)

\section{HASIL DAN PEMBAHASAN}

Tabel 1. Hasil Analisis Regresi Linier Berganda

\begin{tabular}{|c|c|c|c|c|c|c|}
\hline \multirow[b]{2}{*}{ Model } & & \multicolumn{2}{|c|}{$\begin{array}{c}\text { Unstandardized } \\
\text { Coefficients }\end{array}$} & \multirow{2}{*}{$\begin{array}{c}\text { Standardized } \\
\text { Coefficients }\end{array}$} & \multirow[b]{2}{*}{$\mathrm{t}$} & \multirow[b]{2}{*}{ Sig. } \\
\hline & & B & Std. Error & & & \\
\hline \multirow[t]{8}{*}{1} & (Constant) & -206.449 & 602.701 & & -.343 & .733 \\
\hline & PDB & .000 & .000 & .177 & 2.248 & .029 \\
\hline & SBI & -158.267 & 63.605 & -.224 & -2.488 & .016 \\
\hline & KURS & -.109 & .064 & -.360 & -1.708 & .094 \\
\hline & DJI & .302 & .051 & 1.225 & 5.925 & .000 \\
\hline & ASX & -.172 & .176 & -.171 & -.978 & .333 \\
\hline & SSE & -.087 & .052 & -.103 & -1.679 & .099 \\
\hline & STI & 1.010 & .307 & .379 & 3.286 & .002 \\
\hline
\end{tabular}

Sumber: Hasil pengolahan data penelitian, 2017

\section{Pengaruh PI}

Hasil uji analisis regresi menunjukkan bahwa PDB berpengaruh positif dan signifikan terhadap IHSG, hal ini menunjukkan hipotesis 1 yang diajukan terbukti. Arah positif mengkonfirmasi penelitian yang dilakukan oleh Sangkyun (1997), Hooker (2004), Chiarella, Gao (2004) dan Wijayanti dan Kaluge (2013).

Meningkatnya PDB merupakan sinyal yang baik (positif) untuk investasi dan sebaliknya. Meningkatkan PDB mempunyai pengaruh positif terhadap daya beli konsumen sehingga dapat meningkatkan permintaan terhadap produk perusahaan. Peningkatan permintaan terhadap produk perusahaan akan meningkatkan profit dan akhirnya akan meningkatkan harga saham perusahaan.

Jika pertumbuhan ekonomi membaik maka daya beli masyarakatpun akan meningkat, dan ini merupakan kesempatan bagi perusahaan-perusahaan untuk meningkatkan penjualannya. Dengan meningkatnya penjualan perusahaan, maka kesempatan perusahaan memperoleh keuntungan juga akan semakin meningkat (Tandelilin, 2010). suku bunga berpengaruh negatif dan signifikan terhadap IHSG, jadi hipotesis 2 yang diajukan dalam penelitian ini terbukti. Arah negatif menunjukkan dengan adanya peningkatan suku bunga akan menurunkan IHSG di pasar Modal Indonesia. Hasil ini sesuai dengan Tandelilin (2010) yang menyatakan peningkatan suku bunga yang diisyaratkan atas investasi pada suatu saham, menyebabkan investor menarik investasinya pada suatu saham dan memindahkannya pada investasi berupa tabungan maupun deposito.

Peningkatan suku bunga Sertifikat Bank Indonesia (SBI) akan meningkatkan tingkat bunga tabungan, deposito maupun obligasi di pasar modal. Peningkatan suku bunga obligasi akan meningkatkan yield yang diperoleh pemegang obligasi dan menyebabkan ketertarikan pemegang saham untuk beralih membeli obligasi. Adanya pelepasan kepemilikan sahan oleh pemegang saham dan beralih membeli obligasi menyebabkan harga saham akan menurun sehingga IHSGjuga akan menurun. 
Murtianingsih (2012) juga menemukan bahwa tingkat suku bunga berpengaruh negatif signifikan terhadap pergerakan harga saham gabungan, begitu pula hasil penelitian Chabachib dan Witjaksono (2011) menunjukkan bahwa variabel tingkat suku bunga SBI berpengaruh negatif terhadap IHSG.

\section{Pengaruh Kurs terhadap IHSG}

Hasil uji analisis regresi menunjukkan bahwa Nilai tukar berpengaruh negatif namun tidak signifikan terhadap IHSG, sehingga hipotesis 3 yang diajukan dalam penelitian ini tidak terbukti.

Pengaruh negatif menunjukan bahwa semakin banyak rupiah yang ditukar untuk satu dolar Amerika Serikat atau rupiah dalam keadaan terdepresiasi akan menyebabkan terjadinya penurunan Indeks Harga Saham Gabungan di Bursa Efek Indonesia. Hal ini sejalan dengan teori yang dikemukakan Tandelilin (2010) yang menyatakan bahwa menguatnya nilai tukar Rupiah merupakan sinyal positif bagi investor di pasar modal, artinya apabila nilai tukar Rupiah menguat maka Indeks Harga Saham Gabungan (IHSG) akan meningkat, begitu juga sebaliknya apabila nilai tukar Rupiah melemah maka Indeks Harga Saham Gabungan (IHSG) akan menurun.

Pengaruh negatif kurs terhadap IHSG yang tidak signifikan menunjukkan bahwa pemegang saham di Bursa Efek Indonesia tidak mempertimbangkan perubahan kurs dalam melakukan analisis investasi sahamnya

\section{Pengaruh DJI terhadap IHSG}

Hasil uji analisis regresi menunjukkan bahwa indeks Dow Jones (DJI) berpengaruh positif dan signifikan terhadap IHSG dan hipotesis 4 yang diajukan dalam penelitian ini, terbukti.

Indeks Dow Jones merupakan rata-rata indeks harga saham terbesar di dunia yang berada di Pasar Modal Amerika, oleh karena itu pergerakan indeks Dow Jones dapat mempengaruhi hampir seluruh indeks harga saham dunia termasuk IHSG di Indonesia. Signifikansi yang ditunjukkan pada hasil penelitian ini menunjukkan bahwa investor di Indonesia sangat mempertimbangkan pergerakan DJI sebagai dasar acuan keputusan investasi. Pengaruh perubahan indeks Dow Jones terhadap IHSG telah menunjukkan bahwa pasar modal Amerika dan Indonesia terintegrasi.

Hasil penelitian ini menunjukkan bahwa indeks Dow Jones (DJI) berpengaruh positif dan signifikan terhadap IHSG yang mengkonfirmasi dan sejalan dengan penelitian yang telah dilakukan oleh Wijayanti (2013), Budi dkk. (2013), Chabachib dan Ardian
(2011) yang menyatakan bahwa DJI berpengaruh positif dan signifikan terhadap IHSG.

\section{Pengaruh ASX terhadap IHSG}

Hasil uji pada Tabel 1 menunjukkan bahwa indeks ASX200 berpengaruh negatif namun tidak signifikan terhadap IHSG periode Januari 2011Desember 2015. Berdasarkan perhitungan tersebut, telah menunjukkan bahwa hipotesis 5 yang diajukan dalam penelitian ini, yaitu "Indeks ASX200 berpengaruh negatif dan signifikan terhadap IHSG" tidak terbukti. Penelitian ini memperoleh hasil yang sama dengan Johan (2007), namun hasil penelitian ini berbanding terbalik dengan penelitian yang dilakukan oleh Mansur (2005) dan Bisyria (2010).

Situasi perekonomian yang tidak baik saat periode penelitian berlangsung di Australia ini tidak digunakan investor di Indonesia sebagai dasar acuan keputusan investasi, karena pada hasil penelitian ini indeks ASX berpengaruh terhadap IHSG namun tidak signifikan.

\section{Pengaruh SSE terhadap IHSG}

Hasil uji pada Tabel 1 menunjukkan bahwa indeks SSE berpengaruh negatif namun tidak signifikan terhadap IHSG periode Januari 2011Desember 2015. Berdasarkan perhitungan tersebut, telah menunjukkan bahwa hipotesis 6 yang diajukan dalam penelitian ini, yaitu "Indeks SSE berpengaruh positif dan signifikan terhadap IHSG" tidak terbukti. Hasil penelitian ini sejalan dengan i penelitian Tamara (2013) dan Endri (2009:136) Shanghai Stock Exchange Composite Index secara langsung berpengaruh negatif namun tidak signifikan terhadap Indeks Harga Saham Gabungan.

Shanghai Stock Exchange Composite Index secara langsung berpengaruh negatif dan tidak signifikan terhadap Indeks Harga Saham Gabungan dikarenakan hubungan perdagangan antara Indonesia-Cina telah semakin berkembang seiring penandatanganan ASEAN-China Free Trade Agreement (ACFTA) namun tidak diikuti dengan semakin menguatnya hubungan pasar modal antar kedua negara. Hal ini mendukung penelitian yang menyatakan bahwa derajat integrasi baik pasar saham antara negara ASEAN-5, termasuk termasuk Indonesia dengan Cina masih rendah.

\section{Pengaruh STI terhadap IHSG}

Hasil uji pada Tabel 5.6 menunjukkan bahwa indeks Straits Times (STI) berpengaruh positif dan signifikan terhadap IHSG periode Januari 2011Desember 2015. Berdasarkan perhitungan tersebut, 
telahmenunjukkan bahwa hipotesis 7 yang diajukan dalam penelitian ini, yaitu "Indeks Straits Times berpengaruh positif dan signifikan terhadap IHSG" terbukti.

Indeks Straits Times (STI) merupakan rata-rata indeks harga saham di Pasar Modal Singapura. Indonesia dan Singapura merupakan negara anggota ASEAN yang memiliki perjanjian ekonomi yaitu AFTA, dimana AFTA merupakan perjanjian ekonomi perdagangan bebas di kawasan Asia Tenggara. Hal ini menyebakan ekonomi kedua negara memiliki hubungan. Hubungan ekonomi tersebut dapat dilihat dari pasar modal pada masingmasing negara, dimana dengan adanya kebebasan investor Indonesia untuk menginvestasikan dananya di Pasar Modal Singapura dan begitu juga sebaliknya, investor Singapura dapat berinvestasi di Pasar Modal Indonesia. Hasil penelitian ini menunjukkan bahwa STI berpengaruh positif terhadap IHSG yang berarti setiap kenaikan STI mengakibatkan juga kenaikan terhadap IHSG. Kenaikan tersebut terjadi akibat perkembangan ekonomi di kedua negara. Kenaikan indeks Straits Times memberikan sentimen positif bagi para investor di Pasar Modal Indonesia yang mendorong kenaikan IHSG. Signifikansi yang ditunjukkan pada hasil penelitian ini menunjukkan bahwa investor di Indonesia sangat mempertimbangkan pergerakan STI sebagai dasar acuan keputusan investasi.

Hasil penelitian ini menunjukkan bahwa indeks Straits Times berpengaruh positif dan signifikan terhadap IHSG yang mengkonfirmasi dan sejalan dengan penelitian yang telah dilakukan oleh Sidiq (2010) bawha STI berpengaruh positif dan signifikan terhadap IHSG. Peneilitian yang dilakukan oleh Lailia dkk. (2014) dan Habsari (2014) juga telah menunjukkan bahwa Indeks Straits Times (STI) berpengaruh positif terhadap Indeks Harga Saham Gabungan (IHSG).

\section{SIMPULAN DAN SARAN Simpulan}

Berdasarkan hasil analisis data maka dapat ditarik simpulan bahwa PDB berpengaruh positif signifikan terhadap IHSG mengindikasikan pertumbuhan ekonomi, semakin tinggi PDB berarti pendapatan masyarakat meningkat, Meningkatnya PDB merupakan sinyal yang baik (positif) untuk investasi dan sebaliknya. Meningkatkan PDB mempunyai pengaruh positif terhadap daya beli konsumen sehingga dapat meningkatkan permintaan terhadap produk perusahaan. Adanya peningkatan permintaan terhadap produk perusahaan akan meningkatkan profit perusahaan dan pada akhirnya dapat meningkatkan harga saham perusahaan.
SBI berpengaruh negatif signifikan terhadap IHSG menunjukkan bahwa peningkatan suku bunga yang diisyaratkan atas investasi pada suatu saham, meyebabkan investor menarik investasinya pada suatu saham dan memindahkannya pada investasi berupa tabungan maupun deposito.

Kurs berpengaruh negatif namun tidak signifikan bila rupiah melemah maka IHSG aan menguat begitu pula sebaliknya namun pengaruh ini tidak signifikan menunjukkan bahwa investor di pasar modal Indonesia tidak memgunakan perubahan kurs sebagai bahan pertimbangan untuk melakukan investasi saham.

Indeks Dow Jones (DJI) berpengaruh positif dan signifikan terhadap Indeks Harga Saham Gabungan (IHSG) membuktikan bahwa meningkatnya indeks Dow Jones akan mengakibatkan peningkatan pada IHSG yang artinya ada sentimen positif para investor di Pasar Modal Indonesia terhadap kenaikan indeks Dow Jones, begitupula sebaliknya apabila indeks Dow Jones mengalami penurunan akan mengakibatkan penurunan pada IHSG yang artinya ada sentimen negatif investor Indonesia atas penurunan indeks Dow Jones. Signifikansi yang ditunjukkan pada hasil penelitian ini menunjukkan bahwa investor di Indonesia sangat mempertimbangkan pergerakan DJI sebagai dasar acuan keputusan investasi.

Indeks ASX200 berhubungan negatif namun tidak signifikan terhadap IHSG menunjukkan bahwa penurunan ASX200 akan mengakibatkan kenaikan IHSG, begitu juga sebaliknya peningkatan ASX200 akan menyebabkan penurunan terhadap IHSG. ASX200 berhubungan tidak signifikan menandakan bahwa kenaikan atau penurunan ASX200 cenderung kurang memberikan sentimen apapun bagi investor di Pasar Modal Indonesia.

Indeks SSE berhubungan negatif namun tidak signifikan terhadap IHSG menunjukkan bahwa penurunan SSE akan mengakibatkan kenaikan IHSG, begitu juga sebaliknya peningkatan SSE akan menyebabkan penurunan terhadap IHSG namun pengaruh ini tidak signifikan yang menunjukkan bahwa investor di Indonesia tidak mempertimbangkan pergerakan SSE sebagai dasar acuan keputusan investasi.

Indeks Straits Times (STI) berhubungan positif dan signifikan terhadap IHSG membuktikan bahwa meningkatnya STI akan mengakibatkan peningkatan pada IHSG yang artinya ada sentimen positif para investor di Pasar Modal Indonesia terhadap kenaikan STI, begitu pula sebaliknya apabila STI mengalami penurunan akan mengakibatkan penurunan pada IHSG yang artinya ada sentimen negatif investor Indonesia atas penurunan STI. Signifikansi yang 
ditunjukkan pada hasil penelitian ini menunjukkan bahwa investor di Indonesia sangat mempertimbangkan pergerakan STI sebagai dasar acuan keputusan investasi.

Hasil pengujian koefisien determinasi $\left(\mathrm{R}^{2}\right)$ mengenai Hubungan variabel bebas dalam memengaruhi variabel terikat, yaitu sebesar 0,90 atau 90 persen, sedangkan sisanya sebesar 10 persen dihubungani oleh variabel lain yang tidak dimasukkan dalam model penelitian ini. Hal tersebut berarti masih ada variabel lain yang juga berhubungan terhadap Indeks Harga Saham Gabungan namun tidak digunakan dalam penelitian ini.

\section{Saran}

Berdasarkan pembahasan hasil penelitian dan simpulan di atas, maka saran yang dapat diberikan yaitu, penelitian ini menemukan bahwa indeks ASX200 dan SSE berpengaruh tidak signifikan terhadap Indeks Harga Saham Gabungan (IHSG), sehingga disarankan penelitian selanjutnya agar menambahkan indeks harga saham pada pasar modal di negara lain yang memiliki hubungan perdagangan internasional dengan Indonesia seperti Hongkong (Hanseng) ataupun Taiwan yang memiliki hubungan dengan IHSG yang tidak dijelaskan dalam penelitian ini (10\%).

Bagi para investor yang berinvestasi di Pasar Modal Indonesia hendaknya memperhatikan pergerakan indeks Dow Jones (DJI), dan Indeks Straits Times (STI) sebagai acuan atau pertimbangan untuk melakukan keputusan investasi dan diversifikasi internasional karena berdasarkan hasil penelitian ini DJI, SSE dan STI berhubungan signifikan terhadap IHSG.

\section{REFERENSI}

Alkhairani. 2012. Analisis Pengaruh Indeks Saham Asia Terhadap Indeks Harga Saham Gabungan (IHSG) di Bursa Efek Indonesia (BEI) Periode 2009-2011.

Andiyasa, Agus. 2014. Pengaruh Beberapa Indeks Saham dan Indikator Ekonomi Global Terhadap Kondisi Pasar Modal Indonesia. Tesis. Program Pascasarjana Universitas Udayana.

Aviral, Kumar Tiwari., Arif, Billah., Dar, Niyati Bhanja., and Aasif Shah. 2013. Stock Market Integration in Asian Countries: Evidence from Wavelet Multiple Correlations. Journal of Economic Integration, 28 (3).

Bodie, Zvi., Marcus, Alan J., and Kane, Alex. 2014. Investment,Terjemahan: Zuliani Dalimunthe dan Budi Wibowo. Jakarta: Salemba Empat.

Budi, Sutanto., Werner R., Murhadi., dan Endang Ernawati. 2013. Analisis Pengaruh Ekonomi
Makro, Indeks Dow Jones dan Nikkei 225 Terhadap Indeks Harga Saham Gabungan (IHSG) di BEI Periode 2007-2011. Calyptra: Jurnal Ilmiah Mahasiswa Universitas Surabaya, 2 (1).

Chabachib, H. M., dan Wijaksono, Ardian Agung. 2011. Analisis Pengaruh Fundamental Makro dan Indeks Harga Global terhadap IHSG. Jurnal Karisma, 5 (2).

Chandra Utama. 2008. Pengaruh Pasar Saham Dunia terhadap Pasar Saham Indonesia. Surabaya: The Second Conference UKWMS.

Fajar, Budhi Darmawan. 2009. Pengaruh Indeks DJI, FTSE 100, NKY 225 dan HSI Terhadap Indeks Harga Saham Gabungan Sebelum, Ketika dan Sesudah Subprime Mortgage Pada Tahun 2006-2009. Tesis. Fakultas Ekonomika dan Bisnis Universitas Gadjah Mada.

Gallali, Mohamed Imen., and Kilani, Besma. 2010. Stock Markets Volatility and International Diversification. Journal of Business Studies Quarterly, 1(4): 21-34.

Ghozali, Imam. 2006. Aplikasi Analisis Multivariate dengan Program SPSS. Semarang: Badan Penerbit Universitas Diponegoro.

Habsari, Ayu. 2014. Pengaruh Indeks Harga Saham Regional Asia dan Nilai Tukar Mata Uang terhadap Indeks Harga Saham Gabungan (IHSG) di Bursa Efek Indonesia (Periode 20092013). Jurnal Ilmiah Universitas Bakrie, 2 (4).

Hasibuan, Ali Fikri., dan Hidayat, Taufik. 2011. Pengaruh Indeks Harga Saham Global terhadap Pergerakan Indeks Harga Saham Gabungan (IHSG). Jurnal Keuangan dan Bisnis, 3 (3): 262-276.

Hidayah, Nurul. 2012. Pengaruh Indeks Bursa Asia Tenggara Terhadap Indeks Harga Saham Gabungan (IHSG) di Bursa Efek Indonesia. Jurnal Fakultas Ekonomi Universitas Gunadarma.

Husnan, Suad. 2009. Dasar-Dasar Teori Portofolio dan Analisis Sekuritas. Yogyakarta : UPP STIM YKPN.

Ioana, Moldovan., dan Claudia Medrega. 2011. Correlation of International Stock Markets Before and During the Subprime Crisis. The Romanian Economic Journal, 14 (40): 173193.

Jogiyanto Hartono, 2009, Teori Portofolio dan Analisis Investasi, Edisi Keenam. Yogyakarta: BPFE.

Karim, Bakri Abdul., and Majid, M. Shabri Abd. 2010. Does trade matter for stock market integration. Journal : Studies in Economics and Finance, 27 (1): 47-66. 
Kasim, Muh. Yunus. 2010. Pengaruh Indeks Harga Saham Regional Terhadap Indeks Harga Saham Gabungan Di Bursa Efek Indonesia. Jurnal Media Litbang Sulteng, 3 (1): 27-32.

Kuncoro, Mudrajad. 1996. Manajemen Keuangan Internasional Pengantar Ekonomi dan Bisnis Global. Yogyakarta: BPFE-Yogyakarta

Lailia, Hilya., Darminto., dan Hidayat, R. Rustam. 2014. Pengaruh Tingkat Suku Bunga, Tingkat Inflasi, Nilai Kurs Dollar dan Indeks Straits Times terhadap Indeks Harga Saham Gabungan (Studi Pada Bursa Efek Indonesia Periode Januari 2010-Juni 2013). Jurnal Administrasi Bisnis, 12 (1): 1-10.

Ludovicus, Sensi Wondabio. 2006. Analisis Hubungan Indeks Harga Saham Gabungan (IHSG) Jakarta (JSX), London (FTSE), Tokyo (NIKKEI) dan Singapura (SSI). Simposium NasionalAkuntansi 9 Padang.

Mansur, Moh. 2005. Pengaruh Indeks Bursa Global Terhadap Indeks Harga Saham Gabungan (IHSG) Pada Bursa Efek Jakarta (BEJ) Periode Tahun 2000-2002. Sosiohumaniora 7(3): $203-219$.

Mustikaati, Anna. 2007. Analisis Keterkaitan Indeks Harga Saham Gabungan Bursa Efek Jakarta dengan Indeks Bursa Saham Regional. Skripsi Departemen Ilmu Ekonomi Fakultas Ekonomi dan Manajemen Institut Pertanian Bogor.

Muzammil, Ahmad. 2011. Analisis Pengaruh Indeks Saham Asia Tenggara terhadap Indeks Harga Saham Gabungan (IHSG) di Bursa Efek Indonesia. Skripsi Universitas Pembangunan Nasional "Veteran", Jakarta.

Nikunj, R. Patel., Sushil Mohanty., and Neeta Pathak. 2012. Are Stock Markets Interdepedndent ? A Study On Selected Stock Markets. Asian Journal of Research in Business Economics and Management, 2 (11).

Panagiotis E. Dimitropoulos. 2008. International Stock Market Integration: Evidence from Canada, China and The United Kingdom. Journal Economics, Management, and Financial Markets, 3 (1): 37-61.

Sakthivel, P., Bodkhe, Naresh., and Kamaiah, B. 2012 Correlation and Volatility Transmission across International Stock Markets: A Bivariate
GARCH Analysis. International Journal of Economics and Finance, 4 (3): 253-264.

Shevanda, Febrilia Tamara. 2013. Pengaruh Dow Jones Industrial Average, Deutscher Aktienindex, Shanghai Stock Exchange Composite Index, dan Straits Times Index Terhadap Indeks Harga Saham Gabungan di Bursa Efek Indonesia (Periode 2010 - 2012). Jurnal Fakultas Ekonomi dan Bisnis Universitas Brawijaya, Malang.

Sidiq, Ahmad. 2010. Pengaruh Indeks Saham STI, TAIEX, KOSPI, HANGSENG Terhadap Indeks Harga Saham Gabungan Pada BEI. Jurnal Riset Manajemen dan Akuntansi, 1 (2).

Soros, George. 2008. Paradigma Baru Pasar Finansial: Memahami Krisis Saat Ini dan Bagaimana Menghadapinya. Penerbit Daras Book (Zahra).

Srikanth, P., and Aparna, K . 2012. Global Stock Market Integration - A Study of Select World Major Stock Markets. Journal of Art, Science \& Commerce, 3 (1): 203-211.

Sugiyono. 2010. Metode Penelitian Kuantitatif Kualitatif dan $R \& D$. Penerbit ALFABETA.

Sukirno, Sadono. 2010. Teori Pengantar Makroekonomi. Jakarta: Rajawali Pers.

Sunariyah. 2006. Pengantar Pengetahuan Pasar Modal. Yogyakarta: UPP AMP YKPN.

Tandelilin, Eduardus. 2010. Portofolio dan Investasi Teori dan Aplikasi. Yogyakarta : Kanisius.

Trivedi, Jatin., and Birau, Ramona. 2013. Investigating international transmission patterns of stock Prince Volatilitas. Journal ISBN: 9781-61804-192-0.

Utama, Made Suyana. 2008. Aplikasi Analisis Kuantitatif. Edisi Ketiga. Diktat Kuliah pada Fakultas Ekonomi Universitas Udayana.

Wijayanti, Anis. 2013. Pengaruh Beberapa Variabel Makroekonomi dan Indeks Pasar Modal Dunia Terhadap Pergerakan Indeks Harga Saham Gabungan (IHSG) di BEI. Jurnal Ilmiah Fakultas Ekonomi dan Bisnis Universitas Brawijaya, Malang.

Yuliati S. H., dan P., Handoyo. 2005. Manajemen Keuangan Internasional. Yogyakarta: Andi. www.finance.yahoo.com 